\title{
The Hazards of the Right to an Education
}

A study of the schooling of migrant worker children in Chengdu

\section{Chloé Froissart}

\section{OpenEdition}

\section{Journals}

Édition électronique

URL : http://journals.openedition.org/chinaperspectives/386

DOI : 10.4000/chinaperspectives.386

ISSN : 1996-4617

Éditeur

Centre d'étude français sur la Chine contemporaine

Édition imprimée

Date de publication : 1 août 2003

ISSN : 2070-3449

\section{Référence électronique}

Chloé Froissart, "The Hazards of the Right to an Education », China Perspectives [En ligne], 48 | julyaugust 2003, mis en ligne le 20 décembre 2006, consulté le 28 octobre 2019. URL : http:// journals.openedition.org/chinaperspectives/386 ; DOI : 10.4000/chinaperspectives.386

Ce document a été généré automatiquement le 28 octobre 2019.

(c) All rights reserved 


\title{
The Hazards of the Right to an Education
}

\author{
A study of the schooling of migrant worker children in Chengdu
}

Chloé Froissart

\section{NOTE DE L'ÉDITEUR}

Translated from the French original by Peter Brown

1 Education for all is both a basic civil right and a determining factor in a country's development. It is not, however, universally guaranteed in the People's Republic of China. This is especially true for the hundreds of thousands of children from the countryside whose parents have come to the city in search of employment. Excluded from the urban education system until 1996, only a fraction of these children now have access to it in circumstances that are turning them, as a group, into victims of discrimination. Yet, the 1982 Chinese Constitution stipulates that "the citizens of the People's Republic of China have the right as well as the duty to receive an education" (art. 46). In 1986, China introduced a system of compulsory education lasting nine years for every child from the age of six or seven and ratified the United Nations Charter on the Rights of the Child as well as the International Convention on Economic, Social and Cultural Rights, both of which mention the right to an education. So, how can we understand that this right is not guaranteed, while it is constantly being reaffirmed by the Chinese state? A number of community initiatives have come about to alleviate the difficulties that migrant children have in gaining access to public education. Thus some non-government schools specialising in accommodating these children have been created. Yet, does the education that these schools offer their pupils enable them to counter the discrimination of which they are victim? How can we explain the difficulties that these schools are encountering in trying to obtain a guarantee from the state and what strategies are they implementing to gain public recognition?

A worrying situation 
2 The problem is an urgent one, and we can guess that it is going to become more acute by dint of the increase both in family migrations and in the length of their stay in the cities ${ }^{1}$. As early as 1996, the State Commission for Education estimated the number of school-age migrant children to be between two and three million ${ }^{2}$. This can only be an approximation, doubtless on the low side, as the long, complicated and costly formalities that migrants have to go through in order to be allowed to reside and work in the cities mean that many of them remain illegal and so do not show up in the census. Their numbers have been put at 100 million by the Chinese government and at 120 million by Human Rights in China ${ }^{3}$. Out of a sample of 102 migrant workers who we interviewed in Chengdu, the capital of Sichuan province, 36\% have come with their children and nearly three-quarters wish to settle in the city. This means that many children, who would be regarded as being from the countryside given that this status is passed on from one generation to the next, are in actual fact yet to join their parents in the city or be born there ${ }^{4}$.

3 The reason why these children come to the city in the first place is because they have no chance to continue their studies in the country. The education system in rural areas, which receives much less state support than in the cities $\left({ }^{5}\right)$, is not in a position to offer them an education that would enable them to have a better future than their parents had. How can we explain the fact that these children do not have access to the same conditions for study as city residents do?

Institutional barriers

4 Chinese society rests on a fundamental institution, the system of residence (hukou), which appears neither in the Constitution nor in the laws of the country but was gradually introduced by administrative regulations during the course of the 1950 s ${ }^{6}$ in order to respond to the need for social control and to the choices made by the regime for economic development. During the Maoist period, it was the cornerstone of a broader economic and administrative package identifying people in terms of their place of registration and conferring on them rights that varied in relation to their place in the system of production. While the state took direct responsibility for "the iron bowl of rice" 7 of city dwellers, rural communities had to rely on their own strengths, at the same time as producing the surpluses necessary to finance industrialisation. The reforms had the effect of making the system of residency more flexible, and the movement of people became tolerated to accommodate the needs of the market economy, but it still remains in force and is blocking the emergence of any real citizenry. Belonging to society is still a function of one's place of registration. The education of children, like all other social rights, is guaranteed by local governments only for their own constituents. That is why the right to an education, recognised under Chinese law, has no legal value for the children who reside in a place that is different to the one in which they are registered. The system of the hukou, increasing as it does the risk and cost of migration, is deliberately kept in place by the Chinese authorities who fear being confronted by a massive and uncontrollable rural exodus. Migrations have to enable the urban economy's needs in terms of labour to be met as they arise without jeopardising the demographic balance between the cities and the countryside.

5 This system for managing and controlling the population was strengthened by the decentralisation laws that began to be put in place from the early 1980s. The Law on Compulsory Education in the People's Republic of China ( ${ }^{8}$ ), passed at the Fourth Conference 
of the Sixth National People's Congress on April 12 $2^{\text {th }} 1986$, introduced a system of compulsory schooling comprising the six years of primary education and the three years of junior secondary, but transferred the responsibility and management of education to local governments. "The educational sphere, under the authority of the State Council, is the responsibility of local governments, with its management being decentralised" (art. 8). The Law on Education in the People's Republic of China $\left({ }^{9}\right)$, voted for in 1995, strengthened the principle of "local responsibility and a graded management structure" (difang fuze, fenji guanli). Primary and secondary education are first and foremost a matter for the cantons in the rural areas and for the districts in the cities, with higher education coming under the auspices of the provinces (arts. 14 and 15). In other words, at the very time when the Chinese state was undertaking economic reforms aimed at the market economy posited on the free circulation of people, the nature of the administrative reforms that it introduced ran counter to the guarantee of individual rights by making them subject to the condition of territorial management.

It is in these circumstances that we must understand the publication of the Temporary Measures for the Schooling of Children and Adolescents from the Migrating Population by the State Commission for Education and the Ministry for Public Security in 1998 (the 1998 Measures) ${ }^{10}$. While these measures allowed migrant children to enrol in public schools in the cities as well as the setting up of specialist non-government schools to receive them, they were an attempt on the one hand to regain control of the situation on the ground, in particular the appearance of illegal schools, and on the other to endorse discriminatory practices against this population more even than to put up institutional barriers to the equality of rights as such.

7 First of all, as their name suggests, they were temporary measures that proposed temporary solutions by tinkering with an institutional system without undermining it. They were in no way concerned to encourage pupils to have their schooling somewhere other than where their hukou is registered. The measures explicitly brought about a transfer of responsibility from rural to urban governments regarding the compulsory education of children with more than six months' residence in a city and who do not have either parents or a guardian in a rural area. However, they have not been accompanied by any transfer of funds required for their implementation. Local governments continue to allocate resources to education in relation to the number of their permanent residents ${ }^{11}$. Children who have been resident in a city for several years are therefore still in fact deprived of the public assistance to which they are rightfully entitled by law. Moreover, these measures are minimalist (no specific mention is made about urban governments being required to "create favourable conditions for compulsory schooling for children from a migrant population background"), carrying little obligation (no control system having been provided), and leave a good deal of room for manoeuvre to "the People's governments in the provinces, the autonomous regions and the municipalities under direct administration [that] determine measures to be applied in relation to their situation" (art. 18). These measures illustrate what has become, in popular parlance, the unofficial slogan of decentralisation: "the centre proposes, local government disposes" (zhongyang you zhengce, difang you duice).

The state school: a "melting pot" of inequalities and a factor of marginalisation

8 The 1998 Measures state that children of migrants must be first and foremost educated "temporarily" (jiedu) in state schools. But this permission to enrol is subject to 
conditions and does not come with any guarantee. It concerns only "legal" children with a temporary city residence permit and who were not born outside the plan. The rural and urban governments are requested to co-operate in order to strictly control this group of people. Migrant children are required to be registered with the government of their village and the body in charge of education in their canton (from which they have to get an authorisation in order to be able to attend school in the city), as well as with their school and the police station in their place of origin. With these papers, they must then file a request with the school closest to their city residence, which is within its rights to refuse admission to the child. In the case of rejection, a second request must be made to the Education office of the place of immigration that will take on the responsibility of "finding a solution through arbitration" (arts. 5 and 8). When we realise the difficulties that the rural population has in gaining access to government agencies, the further problems that it encounters in order to obtain authorisations and the charging of arbitrary taxes of which it is victim, these preliminary steps already appear as an almost insurmountable hurdle to migrant children being able to go to school. They are therefore little adhered to in practice.

The second condition for enrolling migrant children in state schools is an economic one, school fees being fully the responsibility of families. In order to avoid the problem of allocating public resources mentioned above, the 1998 Measures provide for the possibility for urban schools to raise "temporary enrolment taxes" (jiedufei) in accordance with national legislation ${ }^{12}$. The latter makes the Municipal offices of Prices, Finances and Education jointly responsible for setting a benchmark for this tax and submitting it for approval to the provincial government. In Chengdu, the norm is about 400 yuan a semester for primary school and 1,000 yuan a semester for junior secondary ${ }^{13}$. These figures are an average as the amount of this tax varies in reality in relation to the prestige of the schools and the quality of the teaching. Moreover, some schools consider that they must be compensated for accepting students who, in their view, undermine their standards and reputation, and to whom their legal responsibility remains unclear. In actual practice, this levy is therefore at the discretion of the school principal. According to the parents of children at Bashu School, a non-government school in Chengdu specialising in receiving migrant children, it amounts to about 9,000 yuan for the six years of primary school, that is about 1,500 yuan a year. Many schools require full payment of this tax for the six years of primary school or for several years in advance, while the legislation itself stipulates payment by semester. The amounts due are not generally reimbursed in cases where children leave the school, whether they are expelled or their parents decide to withdraw them from the school. In a context of the de facto and non-regulated privatisation of the Chinese education system, the payment of this tax is in addition to the school fees (about 350 yuan for a semester of primary school) as well as to the countless levies arbitrarily put in place by state schools over the past few years for the needs of their day-to-day operation. Thus it is that English, computer science and sport have become fee-paying optional courses which cost, again according to the parents at Bashu School, more than 2,000 yuan a year. These same parents also complain about the dramatic increases in all sorts of unwarranted taxes (luan shou fei): for night classes, sitting examinations, having people supervise in the playground and the canteen, etc. ${ }^{14}$. If the problem is the same for city residents, and this in spite of Chinese law guaranteeing free, compulsory education, these parents, who have emigrated above all for economic reasons, cannot cope with so many expenses and are often forced to take their children out of school. 

exercised by district governments with a stake in it, either directly or indirectly, in so far as it allows them to lighten their expenditure. The implementation of an effective control mechanism turns out to be at the very least illusory, if one thinks that the Chinese state devotes only $2.5 \%$ of its GNP to education-that is less than the great majority of the poorest developing countries, which on average allocate $4 \%$ of their GNP to it (15)-and where, in the absence of any separation of powers, there exist no judicial controls. The only other course of action open to parents is to complain to the administrative bodies in charge of education, under whose jurisdiction the schools are placed ${ }^{16}$. While the "construction taxes" and "support taxes" given to schools, that could add up to several tens of thousands of yuan a year, have been largely abolished in practice following their banning by the central authorities $\left({ }^{17}\right)$, others have appeared in their place. Quite often in China, political campaigns attempt to make up for the failures and contradictions of the system. One such campaign, which began in Chengdu in February 2003, announced the total elimination of the arbitrary raising of taxes by schools by the end of March ${ }^{18}$. In mid-April ( $\left.{ }^{19}\right)$, the media were still calling on parents to denounce the practice, although the authorities denounced the problem themselves. However, we are still far from a political campaign in favour of the right to an education for children from the countryside, particularly given that discrimination is also part of a conscious strategy by the urban authorities to limit the influx of migrants and maximise the profits generated by their labour, at the same time as minimising the cost of social benefits.

11 Added to this institutional discrimination against migrant children is another, popular one, in which the legislation is sometimes complicit. The urban schools-those that are not explicitly obliged by law to do so-are reluctant to accommodate these pupils from the countryside by dint of their supposed "lowly quality" (sushi taidi). This expression not only refers to the often mediocre academic level of these children, attributable to the detrimental state in which the education system in the countryside finds itself, but also carries an essentialist connotation, that is that these children are assumed to have an inherent "flaw" due to a considerable backwardness in their process of "civilisation". They are isolated within the school, with the other students keeping them away from their games or putting them down because they are badly dressed. Moreover, the teachers sometimes put pressure on the school principals to expel the migrants, as they receive bonuses if the students do well in their exams, and so are hostile to these children whose results are generally inferior. Similarly, urban families take a dim view of the increase in the number of migrants in their children's school ${ }^{20}$. For these reasons, no doubt more than to avoid the inadequacy of the ability of urban schools to accommodate these migrant children ${ }^{(21)}$, the 1998 Measures foreshadowed the possibility of creating extra classes in which the migrant children could receive instruction from retired teachers (art. 10), thereby legitimising a "two gear" education system.

Some migrant children see the doors to state schools quite simply being shut to them, even if their parents can afford the school fees. This is the case, for example, of handicapped children: limping may be a reason for refusing a child entry to a school, as he or she "is not the same as the others". Migrant children who are admitted despite their "handicap" do not get any assistance or attention from the teachers. One father tells how his son, who suffers from a mild shaking in his hands and does not write as 
fast as the others, has not been able to carry on with his studies in a state school, as the teachers wipe out what is on the blackboard without waiting for him to finish taking it down and the other students do not want to lend him their exercise books ${ }^{22}$.

The parents whom we have met emphasise that, even when they have the necessary money for a state school, their children are in an environment that is too hostile to allow proper study. They add that, contrary to their mission, state schools prevent social integration: "Right from an early age, the children feel rejected and harbour a feeling of bitterness towards society" ${ }^{23}$.

Is there an alternative to state schools?

To respond to the needs of these children who are excluded from the education system, schools started to spring up in the major urban centres in the mid-1990s through private, informal and spontaneous initiatives. Often set up by the migrants themselves, they attest to a form of self-reliance to deal with a problem to which no-one was providing any solution. One of the earliest of these, the Xingzhi School, was opened in 1994 in a row of huts in a disused lot in Peking by a female teacher from the countryside in Hebei province, after her friends and neighbours, migrant workers like her, had asked her to give a few classes to their children ${ }^{24}$.

The fees for these self-managed and self-funded schools are in Peking no more than 300 yuan a semester ${ }^{25}$ on average, and they "make do" as best they can. Located on the city outskirts where the migrants live, their premises are old flats, single-storey unhealthy houses, or abandoned warehouses that have been refitted. They generally employ a teaching staff without either the experience or the level required; some of whom come from the country, just like some of the school books used. The sanitary, security and teaching conditions are often deplorable, with the children being piled up in small, badly ventilated and badly lit classrooms that are stifling in summer. In these classes that routinely have more than fifty people in them, students of different ages and levels follow the same courses. Few of these schools offer any secondary education. The furniture-tables, chairs, board, etc.-is made in a roughshod way by the school staff or bought cheaply from state schools that sell off their used equipment. Few schools have any playground or sporting equipment ${ }^{26}$.

At the end of 1996, the Peking districts of Haidian and Fengtai had at least seven primary schools set up by and for migrants, that were attended by more than a thousand children ${ }^{27}$. By the end of 2000, in Peking alone, there were over two hundred schools of this kind with more than forty thousand pupils ${ }^{28}$. On account of their growing number and the competition between them, some of the more important schools tried to bring the quality of their teaching and material into line with that of the urban schools. Thus, while the schools with several thousand pupils gradually introduced classes in English and computer studies, those with only a few dozen students are still struggling to provide basic education in Chinese and mathematics ${ }^{29}$.

These schools have no legal status, which means that they cannot award certificates or give status for courses completed, which is a considerable problem when the students wish to re-enter a state school or have the level of their studies recognised for the purpose of finding a job. Moreover, these schools are routinely banned and demolished without the authorities worrying about placing the children in other schools. However, the 1998 Temporary Measures for the Schooling of Children and Adolescents of the Migrant Population announced the possibility for the "social forces" to create "substandard" (jianyi xuexiao) schools for migrant children to which local governments and bodies in 
charge of education are required to give their "active support" (art. 9). But the law stopped there, so that out of the 19 provisions contained in these Measures, only one concerned those schools that specialise in accommodating migrant children. Thus, the civil servants responsible for authorising and controlling these schools, who have "no directive to follow or any idea of government requirements regarding these informal schools", as the director of one of them in Peking laments $\left({ }^{30}\right)$, perfectly naturally referred to the Regulations for the Establishment of Schools by the Social Forces (1997 Regulations) ( ${ }^{31}$ ), drawn up by the State Council in 1997. These regulations have the aim of "encouraging businesses, institutions, associations and other social organisations as well as citizens" to develop the sectors of professional training and adult education, as well as any preceding, following or complementing the period of compulsory schooling (day care, advanced teaching of languages, short courses to prepare for exams, etc.). With regard to the compulsory education system, private initiatives are encouraged in order to "complement" the state sector system when the latter cannot meet the social demand. This has given rise to the creation of what are commonly called the "aristocratic schools" (guizu xuexiao) offering a well-heeled elite better conditions of education. The requirements in terms of the internal organisation and day-to-day operation of these schools, the initial investment and the income, quality of equipment, staff and teaching corps, etc., are in total contradiction to the particular dispensation granted by the 1998 Measures to those schools hosting migrants and are manifestly not adapted to the specific problem of the schooling of these children. The lack of means available to migrants (finance, knowledge and social network), their ignorance of the law as well as the often distant and mistrustful relations that they have with the authorities explain the impossibility in which they find themselves to set up schools in accordance with the criteria laid down by the 1997 Regulations/ or should this be the 1998 Measures?. The latter are to be replaced, from September $1^{\text {st }} 2003$, by the Law for Promoting Non-State School Education in the PRC (32), passed in December 2002 by the Permanent Committee of the National People's Congress. This law will, in any event, do no more than highlight the problem, to the extent that it increases the number of conditions for creating such schools and strengthens control over them. However, the research we have carried out in Chengdu at a new generation of educational establishments reveals that the difficulties facing the schools for the children of migrants in obtaining state recognition go well beyond the mere lack of legislation dealing with them.

The race for recognition

18 We noticed in the Sichuan capital the appearance of a new generation of principals who set up schools for migrant children about a year ago. These are city residents not originally from Chengdu who, both through personal conviction and drawn by the profits to be made, wanted to respond to the needs of a migrant population that continues to swell. Over the course of the nearly ten years that this phenomenon of migrant schools has been evolving, some have seen this sector as a potential source of profit. Thus, before opening his school in Chengdu, the founder of Yangfan School conducted a vast survey in several Chinese cities that looked very much like a marketing study. These new directors have, moreover, been encouraged by a favourable political climate, particularly through the campaign against poverty and by giving help to "weaker social groups" (ruoshi qunti), which was announced at the session of the National People's Congress in March 2002. The people setting up these schools, not being migrant workers themselves, possess the intellectual and financial 
means needed to carry out their plans. The two schools that we have followed the closest (33), Bashu and Yangfan, are based on an initial investment of 200,000 yuan and 500,000 yuan respectively. The founder of the first named, Mrs Xiao Hongtao, from Chongqing, is a former junior secondary school teacher who comes from a long line of teachers in her family, with her brothers and sisters also practising teachers. She claims to have been struck by the sight of children shining shoes in the street instead of going to school. The founder of the second school, Mr Zhou Yong'an, who comes from the province of Jiangxi, has worked as a tertiary teacher and engineer. He says that he wanted to repay his debt to the rural farm workers who had always treated him well when he was sent to the countryside on three occasions during the Maoist period. Both have complied with the Criteria of Sichuan Province for the Establishment of Non-Government Educational Institutions ${ }^{34}$ that set out the criteria that must be met by the school's principal and teaching and administrative staff, by its land, buildings and equipment, as well as the minimum initial investment needed. They have also complied with the Regulations for the Creation of Schools by the Social Forces ${ }^{35}$ published by the Education Office in their local district, that specify the nature of the application required, as well as the way to approach the Education Offices of both the district government, the administrative village's government, the street committee, the office of Public Security, the Office of Prices and finally in the Office of Civil Affairs.

With one or two minor exceptions, these two schools meet the standards required. Yet their existence is threatened. One of them, Bashu, has never received a licence (xukezheng), and the other, Yangfan, is about to lose its licence. They are both located on the outskirts of the city, in poor areas with a heavy concentration of migrants. They do not set any conditions for recruiting students, nor do they require any hukou type paper, temporary residence permit or government authorisation from the applicant's place of origin. As the founder and director of Yangfan school points out, "studying is a right that cannot suffer any condition". The school fees are reasonable, although higher than in the Peking schools set up by migrants, owing to the better quality of the latter (this is saying that the better quality schools are cheaper?). The school fees in Yangfan amount to 500 yuan a semester for the last part of kindergarten and 550 yuan per semester for the first year of primary school, increasing by 10 yuan for each grade thereafter. Bashu, smaller in size, has fees that are slightly higher: 500 yuan a semester for the final year of kindergarten and 650 yuan a semester for all primary classes. These fees remain, however, under the ceiling of 750 yuan a semester set by the municipal authorities for private schools offering classes corresponding to the period of compulsory schooling, and, in line with national legislation, families that are struggling can take advantage of preferential rates, some children even having temporary fee exemption. These schools accommodate a lot of handicapped children who are not accepted or are badly treated in the state schools. The students follow the compulsory curriculum in all subjects, including classes in English, music, sport and computing that are regarded in state schools as being optional and for which the children of migrants are obliged to pay additional fees. The textbooks used are the same as in the state schools.

Yangfan School is located to the northwest of the city, in the district of Chenghua. It comprises a main school at Honghuayan cun (village) and an annex at Qinglong xiang (canton). The teaching ranges from kindergarten to the first year of secondary school. Established in January 2002, the school received a licence the following July. It has the reputation of being the first private school in Chengdu to have taken in children of 
migrants and is also the most important one that we have visited. It has about 1,500 students, spread between 13 classes in the main building and 10 classes in the annex, and employs 52 teachers as well as 8 administrators. The main school is located in an old, refurbished warehouse and, while the conditions are modest, the buildings are in good order. The school has a playground with sporting equipment (ping-pong, basketball court), 40 recycled computers, a modest library and a music room. There are, however, more than fifty pupils per class, which is the maximum allowed under the law.

Bashu School is located to the southwest of the city, in the district of Wuhou. Despite opening its doors in June 2002 and officially beginning to teach classes in September of the same year, the school has still to be granted a licence. The teaching extends from kindergarten to the final year of primary school. The school has 7 classes, one for each grade made up of between 16 and 50 students. Overall, it has 218 students, 14 teachers and two administrators. The teachers, the majority of whom are from the city, are recruited by specialist employment agencies and have all the necessary diplomas, even if they do not always have the experience required by law. The school, which occupies 2,500 square metres of land, has put up buildings especially designed for classroom use. Furthermore, it has a leafy playground area with sporting equipment (basketball court, parallel bars, ping pong), a canteen with on-site kitchens, 10 recycled computers and an electric piano.

These two schools attest to the real efforts made to bring the quality of their teaching and equipment closer to that of urban standards, even if they cannot compete with the flamboyant luxury of the "aristocratic" private schools. In the words of Zhou Yong'an himself, the level of teaching still needs improvement: $60 \%$ of the teaching body in this school comes from the countryside, where the level of training is mediocre, and some teachers do not have the five years experience required by law. Many teachers are in retirement, others come from training departments within companies. In fact, these schools cannot hope to attract teachers as qualified as those in the prestigious state or private schools, due to the lower salaries that they have to offer them: 600 yuan a month at Yangfan, and from 600 to 800 yuan at Bashu, to which must be added bonuses in relation to the quality of teaching. Yangfan School encourages its teachers to follow fee-paying training courses organised by a specialist state school, but the costs have to be borne by the teachers themselves, as the school cannot take on this responsibility, although the legislation dealing with private schools requires them to do so. In spite of these difficulties, these schools offer better educational conditions than schools in rural areas.

The hostility of local governments to these schools specialising in teaching migrant children cannot be explained solely by the apprehension, as real and justified as it may be, of being held responsible for authorising schools that do not provide sufficient guarantees. With the absence of any real legislation or control system a factor, the number of cases of private schools going bankrupt and closing down has been growing considerably over the past few years, with school directors disappearing from one day to the next without reimbursing the money owed to families. However, in the main this concerns private "aristocratic" schools and not schools for migrants. In order to counteract this risk, the Criteria for the Establishment of Non-Government Educational Institutions in the Province of Sichuan set the figure of 200,000 yuan as the minimum initial investment required for a primary school and one million for a junior secondary 
school. The district governments require, moreover, the educational establishments to lodge a bank deposit as surety. In the province of Wuhou this amounts to 60,000 yuan for 320 students and can only be recovered after twenty years. Even if these sums are often prohibitive for the migrant schools, they do at least guarantee compensation for families in case of bankruptcy. The district governments responsible for authorising these schools also refer to their poor material and sanitary conditions to justify their closure. We have already indicated how specious this argument is in a context where the children attending these schools-supposed, by law, to be the subject of special tolerance and support from the authorities-need above all to see that they have a guaranteed minimum level of education. The deeper reasons for this hostility are to be found in conflicts of economic interest. The children of migrants who attend nongovernment schools do not pay the taxes that they are obliged to in the state schools, which amounts to a financial shortfall both for them and for local governments. The latter are also little inclined to allocate land to schools that are exempt from income tax, contrary to businesses. Moreover, granting a licence to a school means subjecting it to regular controls concerning the content and quality of its teaching, its administrative practice and financial management, its conditions of sanitation and security. To guard against this expense, the government of Jingniu district has imposed "management fees" on Caiyi School that it has recognised, while the law states that private schools must receive treatment from the authorities that is equal to that given to state schools. Moreover, the authorities are obliged to create the conditions necessary to enable migrant children to be schooled, in particular by supporting private initiatives ${ }^{36}$. Many bureaucrats in the cities therefore continue to consider that they are not responsible for the compulsory education of non-residents and that they must be compensated, or even remunerated, for this service. Finally, there also exists an image problem that should not be ignored. These schools for migrants look dreadful and are perceived as a element of depreciation in the urban landscape.

All these reasons account for the fact that local governments are doing all they can to keep these schools illegal or have them become illegal. To this end they have recourse to means that not only fly in the face of legislation, but also devalue the image of the public authorities.

Bashu School, awaiting legislation

Before beginning to enrol students, Bashu School made, as prescribed by legislation, a request for authorisation of the government of the administrative village of Yongfen and the Education Office of the government of Wuhou district under whose jurisdiction it falls, but has not received a positive response. We have been able to gain access to all the documentation of Bashu School that its founder and director, Mrs Xiao Hongtao, was kind enough to allow us to consult. We were able to see that the file setting out the request for authorisation was complete, stating the precise status and objectives, justifying the source of the initial capital outlay, and providing a contract for the rent of the land as well as a building plan, all in due form. A personal file was established for each teacher and administrative employee justifying their qualifications. The school clearly maintains its non-lucrative objectives, its statutes specifying that all profits will be reinvested for five years, at the end of which period only $20 \%$ will be distributed to the shareholders. Furthermore, the school has a board that works perfectly well, whereas the Sichuan Province Regulations for the Establishment of Schools by the Social Forces mention the existence of such a body as a possibility and not an obligation. 
Nonetheless, the school has two weaknesses with regard to the Sichuan Province Regulations for the Establishment of Non-Government Educational Institutions. The one concerns its equipment, the other the qualification of its teachers. Lacking are a laboratory for experiments, a library and a music room, although that does not in any way prevent music classes from being held. Moreover, only four teachers out of the ten that the school had at the time of its opening have accreditation, although all have at the very least completed the second year of teacher training college, as laid down in the legislation. As far as the first issue is concerned, none of the schools for migrant children that we visited, some of which have been officially recognised by the state ${ }^{37}$ ), possess all the material required by the Regulations as the investment required is too great for this type of institution and the risk too important in case of a licence application being rejected. Moreover, we have already pointed out that this type of school has had quite some difficulty attracting fully qualified teachers. The six teachers without any accreditation either come from outside of Chengdu and, although having received accreditation in their place of origin, are not recognised by this municipality, or young teachers who have not yet finished the three to five years of practical training required before being able to sit the examination.

On August $15^{\text {th }}$ 2002, Bashu received a notice from the Education Office in Wuhou district that, based on the school's dossier, advised that the land, infrastructure and pedagogical material and quality of teachers did not meet the required standards and that it was therefore not authorising the school to open. It had to cease immediately all advertising and recruitment of students. This notice was followed, on September $3^{\text {rd }}$ 2002, a few days after the start of classes, by a notice of administrative sanction from the Education Office of Wuhou district announcing the closing of the school and, on September 11th, by a decision of administrative sanction from the same office setting the school's date of "eradication" at 30 days after receipt of the letter.

The notice of September $3^{\text {rd }}$ cited article 45 of the Regulations of Sichuan Province for the Establishment of Schools by the Social Forces specifying that schools can only be shut down after a trial period of bringing them up to scratch granted by the authorities and stating that the various attempts at arbitration put in place by the administration had all failed. In terms of arbitration, both the administrative village and district governments sent representatives to stick up posters dazibao vilifying "the illegal school". A campaign of defamation was orchestrated in the local popular press, denouncing the dilapidated state of the place, the incompetence of its teachers and administrators, and accusing its director of employing only family relations and having the lure of gain as his sole motivation ${ }^{38}$. On several occasions, accompanied by considerable numbers of policemen, some bureaucrats went to Bashu to give teachers the order to resign and to tell parents to take their children out of the school in exchange for assistance in seeking employment. The main official in charge of education in the government of the administrative village of Fengxiang, whom the Bashu officials accuse of collusion with the state schools, even personally led a campaign within Bashu School itself, as in the marketplaces and fairs in the surrounding areas, to sing the praises of state schools coming under his administration, affirming that they would cost only 400 yuan a semester in fees for children leaving Bashu. On August $27^{\text {th }} 2002$, in the middle of a heat wave, the local officials cut off the school's water and electricity supply, thereby causing several students and teachers to be affected by the heat. 
29 For its part, Bashu School tried on several occasions to argue its case to the administrative services but received the reply that it would not obtain any authorisation unless it lodged a significant financial surety in the bank (which it did), and then invest 40 million yuan to build a "school with standards", that is to say able to compete with the splendour of "aristocratic" private schools from which local governments raise taxes more or less legally in the form of a percentage of the investment, "construction costs" and other "management fees". According to Bashu School officials, the line that the authorities are taking is one that aims less to guarantee the rights of students and their families than to advance the personal enrichment of bureaucrats. Either a school has the means of getting the authorities interested in its profits and accordingly sees its lucrative objectives encouraged to the contempt of the law ( $\left.{ }^{39}\right)$, or it cannot overcome the economic hurdles that are put in its way and "disappears of its own accord" (zisheng zimie) by going bankrupt. This is the case of Kaiming School in Chongqing, another school that specialises in taking in migrant children, and that had an initial investment of 90 million yuan imposed on it by the authorities. It contracted a loan of 80 million that it was not able to repay ${ }^{40}$. According to this logic, the "schools for the poor" (pingmin xuexiao) always lose out alongside the "schools for the aristocrats" (guizu xuexiao).

Encouraged by the support and action of parents, Bashu School has carried on with its activities, but lives under the constant threat of being "eradicated". This implies not only that the teaching that it offers has no recognised value, but also that the school cannot take the risk of investing to improve the quality of its infrastructure and teaching.

Yangfan School, under threat of losing its status

The difficulties encountered by Zhou Yong'an in trying to get a licence for his school have been similar to those of Bashu School, although the outcome has been a happier one. Zhou Yong'an opened the doors of Yangfan School in January 2002, at the very time when his request for authorisation had just been rejected by the authorities of Chenghua district. In spite of the banning of his school, Zhou Yong'an did not close it and, six months later, obtained a licence thanks to the support of the parents, to the fact that he was able to come to some arrangement with local government bureaucrats and to the help of the local written press and television, which were also liberally compensated for their commitment in favour of the education of migrant children. All this was possible on account of the size of the school, which, in addition, was an instant success with the migrant families themselves. Clearly, smaller schools that have a less significant initial investment and receive fewer students-as is the case of Bashu, but also of two other schools in Chenghua district $\left({ }^{41}\right)$ - cannot spend as much money to gain state recognition.

The problem with the guarantee for this school is not, however, resolved yet, as the government of Chenghua has introduced an annual licence renewal process, despite the fact that national and provincial legislation states that this is only necessary when a school changes its objectives and the content of its teaching, or changes its location ${ }^{42}$. The Criteria of the Province of Sichuan for the Establishment of Non-Government Educational Institutions stipulate that primary schools must provide an area of eight square metres per student. Enrolments have been so significant, however, since the school's opening that the buildings have become largely inadequate. Zhou Yong'an therefore made a request to his district government to lease and build on land adjoining the school's 
main site. The government refused this request, however, preferring to rent it out to a business paying taxes, despite both national and provincial laws stressing that schools have priority in the allocation of land ${ }^{43}$. Zhou Yong'an was therefore forced to destroy some parts of the school, including the canteen, the majority of the teachers' living quarters and the room for experiments in order to put up new classrooms. Children aged between six and seven are thus forced to leave the school at lunchtime to get food from street stalls. Moreover, this solution does nothing to fix the problem as the canteen and the room for experiments are themselves required for obtaining a licence. Since last January, Zhou Yong'an has received several visits from inspectors threatening him with the closure of his school. In the opinion of the school principals themselves whom we met, the strategy of the authorities thus consists in causing these schools to be in infringement of the law so as to prevent them from obtaining a licence or disallow its renewal.

Strategies of resistance

33 Faced with the same arbitrary situation, Bashu and Yangfan have adopted two radically different strategies to protect themselves. One has resolutely chosen to put itself on the side of right and the law, while the other has exploited the dysfunction of the system.

A short time after receiving the first notice of closure of the school, Gan Bingxiang, who was co-founder of Bashu School with his wife, sent a "letter of complaint to the directors" addressed to the government of the administrative village, the Education Offices in the district, the municipality and the province, the Municipal office of Laws and Regulations, as well as the People's Assemblies of the municipality and the province, having recourse in the process to a practice that has been used in China since imperial times. Acting as his own advocate, the letter writer called on the higher leaders to "apply the law with severity and clarity, and maintain rights and equity" (mingjing gaoxuan, bingfa gongzheng), spelling out the objectives and conditions of his school, the steps taken to bring it into line and the difficulties encountered, and scrupulously cited all the articles of law on which his business was based. The letter ended with an appeal to save his school in the name of the right to an education for all and with a warning about the social consequences that are to be feared if this right is not respected. This letter was accompanied by another complaint, spontaneously written by the parents of the schoolchildren, in which they describe the discrimination their children face in state schools as well as their satisfaction with Bashu School ${ }^{44}$. Following receipt of the decision to close the premises, the school also appealed to the Wuhou district People's Tribunal. But the tribunal confirmed the earlier decision and set the closing date at January $1^{\text {st }} 2003{ }^{45}$. In the meantime, the Education Office of the municipality of Chengdu had reacted to the complaint addressed to it by sending in a health inspection team which then declared that the school was abiding by the standards $\left.{ }^{46}\right)$, while the Sichuan Province's People's Congress directly contacted the Wuhou government, calling upon it temporarily to not close down the school. It is, however, extremely risky for the upper ranks of the Administration to disavow those lower down, who are furthermore directly in charge of registering schools, and to overturn the decision of the People's Tribunal of the district of Wuhou that gave a judicial seal of approval to an administrative decision. The Bashu School, bolstered by the findings of the health inspection, went again therefore to its district government that set a new condition for the granting of a licence: the production of a deed of title to the land. This condition does not figure in any law and for good reason, as in China virtually all land belongs to the state. It was not, however, formulated by chance, as the 
land rented by the school has been privatised and belongs to a rich businessman, yet the school remains, theoretically and very hypothetically, protected by the law that declares a long-term rental agreement to be sufficient ${ }^{47}$.

If Bashu School, denouncing the absence of any public service perspective among the bureaucrats, decided to play the legal system against arbitrary decisions, Yangfan School has taken a contrary path. Firmly committed to opening a junior secondary school, a high school and then a university for migrant children, Zhou Yong'an has just rented two plots of land in the administrative village of Qinglong which falls under the jurisdiction of Wuhou district and officially anticipates constructing retirement houses on it. The authorities are much better disposed to this type of structure that is designed for city residents and subject to taxation. The first plot of land, of about one hectare, will house both a primary and a $7,500 \mathrm{~m}^{2}$ junior secondary school. The work is already underway and the schools will open their doors in September. Zhou Yong'an hopes that the authorities, if they are interested in the undertaking, will not dare to destroy the schools once they become a fait accompli. This is far from being clear, however. The director of Yongfan, conscious of the dangers, and in an attempt to avoid the risks, has managed to set up a whole social network around his school and to find various kinds of support in the media ( $\left.{ }^{48}\right)$, academic institutions and mass organisations, that he has been able to bring together thanks to his comments on the inequality of opportunity, the assistance given to migrant workers to settle in the city and the renewal of pedagogic methods. On March $29^{\text {th }}$ Zhou Yong'an sealed a collaboration with the Group of Young Volunteers for Education from the University of Sichuan $\left({ }^{49}\right)$, who signed up to give free lessons in mathematics, Chinese, English, dance and music on weekends to any interested student. The inauguration ceremony was presided over by the officials from the Communist Youth League of Chengdu, the Committees of Young Volunteers of this league at the municipal and university level, and a representative of the Sichuan Academy of Social Sciences, who all spoke in front of Chengdu Television cameras and the educational channel of Sichuan Television in favour of the social commitment of Yangfan's director. Zhou Yong'an was able to take advantage of the political climate introduced by the March 2002 session of the National People's Congress (NPA), and subsequently confirmed at the Sixteenth Congress of the CCP last November, which came out in favour of the fight against social inequality. This was further reaffirmed at the Tenth NPC session in March 2003, when the delegates from the Communist Youth League denounced the inequality of treatment that the migrants are victim of, in particular in terms of education ${ }^{50}$. Zhou Yong'an also skilfully turned the event into a patriotic ceremony, which opened with the national anthem and was held in the school's playground with the flag of the PRC raised and a banner at the entrance celebrating the school's obtaining of a licence. Through this piece of theatre, Zhou Yong'an was keen to show off his school's legality as if to exorcise the precariousness of its status and bear witness to his good and loyal service towards the fatherland at the very same time as the development of his business was more and more prone to being interpreted as a sign of opposition to the government.

Since then, Zhou Yong'an has been hoping to be able to develop this co-operation, with which he is also trying to associate the Centre for Education and Training of the Sichuan Academy of Social Sciences, in three directions. Firstly, by setting up technical training programmes aimed at helping the students to become "little bosses". Secondly, by proposing to parents of school children courses in general culture and professional development in order to help them better settle into life in the city; and thirdly, by 
improving the training of teachers in their respective disciplines, and introducing them to new pedagogical methods that are adapted to migrant children. These projects also have the goal of developing partnerships with official institutions under whose wing the school could be placed. In the interim, however, the Sichuan Academy of Social Sciences has refused to set itself up as an "umbrella institution" (guakao danwei) of the school, which, in exchange for a share in the latter's capital, would have allowed Yangfan to come under the auspices of an official institution and so settle the matter of its status once and for all ${ }^{51}$.

The anomalies of the system

It is thought that there are about ten schools for migrant children in Chengdu. We know five of them, two of which have obtained a licence but one only-Caiyi xuexiaoseems to have had its status assured. The others, "neither eliminated nor recognised" (bu qudi ye bu chengren), find themselves in a precarious position. Local governments are hesitant about closing them, in so far as they have not yet come up with any viable solution to the situation of migrant children whose needs these schools are at least meeting. From a confidential document of the Chenghua district government to which we have had access $\left.{ }^{52}\right)$, it is clear that the tactics of the authorities are to have all the migrant children attend state schools. For that they envisage increasing their capacity to accommodate these children by building annexes. However, nothing is said about the reasons why immigrant parents cannot or will not send their children to state-run schools: yet we have seen how the lower ranks of the Administration have had an interest in maintaining a discriminatory system. If local governments are nervous about closing these schools, it is also because they are running up against the hostility of the people concerned for whom these schools represent the only hope and who have already shown that they are prepared to take action in order to defend them. Finally, the governments in the administrative villages and the districts are in the wrong, something which the upper echelons of power are well aware of, as shown by the support given to Bashu School by the Education office in the municipality of Chengdu and by the People's Congress in Sichuan Province. If these schools are illegal, it is because local governments are refusing to grant them a licence, while the substandard material, teaching and management conditions that they highlight ${ }^{53}$ in order not to authorise these schools are no more than the result of their own policies. The answer to the problem lies rather in regularising these schools and in introducing a system of control and support which would help them to improve their conditions, in accordance with the letter of the law.

In the meantime, migrant children are the first victims of the lack of public recognition of their schools. Their years of study in them have no certified value and they are routinely forced to interrupt their education following the closure of their school. The administration, management and quality of teaching in these schools are not subject to any control and their principals are not encouraged to invest so as to improve the situation. Indeed, in the total absence of any control over profits, the latter are sometimes grabbed by those in charge of the school, and multiple bankruptcies are occurring without the families being compensated or the children schooled elsewhere 54. The students are thus sometimes hostage to the ambition of principals in a context of growing and non-regulated competition. In Peking, in order to attract new clients, some schools for migrants have begun to put in place an expensive infrastructure and to implement new services the cost of which must be borne by the families, who do not always have any other alternative for educating their children. This "commodification" 
of education has already been denounced by Chinese researchers, in particular Han Jialing ${ }^{55}$. In Chengdu, the ambition of Yangfan School is putting the children it is accommodating at risk through its illegal investments. But these schools can just as well turn out to be models of a republican school, as witnessed by the parents of children attending Bashu School. They point out that, contrary to students in state schools, their children are treated with respect and equality, whatever their background. They consider themselves to be very satisfied with their academic progress as well as with their acquisition of fundamental values. Struggling families are to benefit from preferential measures based on social criteria, and handicapped children receive special attention. Relations within the school itself are based on solidarity: the parents are very grateful to the teachers for taking some of their spare time to organise study groups and help those children who are having problems with their school work, staying with them until the parents have finished work or accompanying them back home when they cannot come to collect them. Bashu, like Yangfan, opens its doors on Saturdays and Sundays to offer a place of social interaction to children who are too often left to their own devices. Both of them organise regular meetings with parents to inform them of the school's situation and pedagogical practice and to hear their proposals. This initiative is a clear break with the way in which they are received in state schools where they are neither listened to nor given any information. Yangfan even has its own publication, to which the teachers, students and parents contribute. Free of charge, it gives news of the school, information about the migrant population, in particular legislation concerning them, and offers a platform for supporting parents and students at the school. It has a print-run of 1,500 and the condition for the existence of this gazette is that it is not distributed outside the school. As the mobilisation of parents of children at Bashu shows, "the republican school" could well turn out to be "the school of democracy", unless the authorities rush to regain control of it by regularising these schools.

\section{Forces at work and future perspectives}

While the question of accommodating migrant children was not raised until the latter part of the 1980s, Chinese intellectuals have gradually, since then, become involved in favour of the universal right to education. Researchers, some of whom belong to government think-tanks, have, over the past few years, being publishing detailed reports submitted directly to the government. We have already cited Han Jialing of the Institute of Sociology of the Chinese Academy of Social Sciences (CASS), to whom we could add Wang Chunguang, also from the CASS, as well as Cui Chuanyi and Zhou Shukai of the State Council's Research Centre for Development ${ }^{56}$. Journalists are also playing an important role in the development of thinking and public opinion, from $\mathrm{He}$ Nanying's outcry of protest in 1996 denouncing the emergence of a "new generation of illiterates" ${ }^{57}$ to the recent report by the Nanfang Zhoumo ${ }^{58}$ on the "cleansing" of 16 schools in the Peking district of Fengtai last February. This gathering momentum is having a certain impact on the central government. In May 2001, the State Council published a Decision on the Reform and the Development of Basic Education ${ }^{59}$ that mentioned the need to take account of the education of migrant children by making their acceptance in public schools a priority. Last January, the Ruling on Successfully Managing the Employment of Rural Farm Workers in the Cities and their Access to Public Services ${ }^{60}$ carried a clause stipulating "that the right to compulsory education for the children of migrant workers must be guaranteed". Local governments are required to take steps so that these children can enjoy the same teaching conditions in state schools as city 
residents do and to support any "substandard schools" by bringing them into the development plans for education and helping them to improve their material and pedagogical conditions instead of eliminating them. Finally, urban governments are required to devote a part of their budget to the education of these children.

However, these signs of goodwill often still remain a dead letter in the absence of any detailed and compelling legislation. Thus, the Peking district of Fengtai, which was chosen by the municipal authorities on two occasions, in 1996 and 1998, as a pilot site for testing the national legislation concerning schools for migrants, not only has not contributed to improving conditions in these schools, but has even organised two "cleansing" campaigns, the first of which, in 2001, allowed the "eradication" of 50 schools ${ }^{61}$. The opposition between the central and local authorities is clear. The former are happy just to devise general principles, leaving to the latter the task of elaborating the corresponding legislation and bearing the costs of it.

Since March 2002, however, the beginning of a consensus seems to be emerging over the fact that it is better to prevent a social evil than to cure it. It is this spirit that prevailed at the 16th Congress of the Chinese Communist Party (CCP) last November, whereas the Fifteenth Congress in 1997 had as it were proclaimed the need for a twogeared society for speeding up the economic development of the countryside. With the deepening of the social crisis, the CCP became conscious that the increase in the rate of growth was no longer enough to ensure its legitimacy, so it came to set itself the objective of creating a more egalitarian society of relative prosperity, the latter understood as being more evenly shared. In this context, resolutely reformist voices were heard within the Party and the state, and some initiatives sprang up. Last March, the first session of the Tenth National People's Congress gave a platform to these reformers. We have already mentioned the firm line taken by the Communist Youth League in favour of equality of rights for migrants, in particular concerning education. A group of representatives warned against "the social sickness" which is on the verge of developing if the situation of migrant workers does not receive greater attention. Citing the rising figures of delinquency, one representative commented on them as follows: "respect for society supposes that society respects the dignity of the person" ${ }^{62}$. This point of view is also shared by local executive bodies, as attested by the initiative of Xiamen municipality which, in August 2002, published legislation allowing the regularisation of 34 private schools for migrants and creating a special office responsible for financing, controlling and giving direction to them. The boldness of this initiative should, however, be put in a relative context. Nearly half of the population of Xiamen is not originally from the city and the authorities are conscious that its 30,000 migrant children represent the future of the Special Economic Zone ${ }^{63}$.

Power is thus divided according to divergent interests and points of view, and there is no doubt that this will favour change. The relations between the different rungs of the Administration in Sichuan Province is particularly interesting and creates more favourable prospects for development than in some large cities in eastern China. Indeed, how can one explain that, until now, no campaign for eradicating schools for migrant children has been conducted in Chengdu, whereas such campaigns are regularly organised in cities like Peking, Shanghai and even Shenzhen? We must no doubt see in this the particular character of this city with respect to municipalities under direct administration or the Special Economic Zones in the eastern part of China. On the one hand, Chengdu is facing a massive rural exodus, essentially from the 
province of which it is the capital, contrary to the major eastern cities that are taking in migrants, from the whole of the country, despite having much more tenuous identity and cultural links with them and without having any direct administrative obligation towards them. On the other hand, the capital of Sichuan is a part of the network of urban centres that form the backbone of the policy of development in the west introduced in the summer of 1999 and which are consequently called on to develop, whereas the cities in the east, which have already reached a certain level of development, are on the contrary trying to reduce immigration, thanks to much more radical control measures and selection policies based on socio-economic criteria. Thus, the willingness of the Centre to give assistance and support to disadvantaged social groups runs up against the concerns of the Sichuan People's Congress, which is supposed to represent the whole of the provincial population. The latter has not only given its support to Bashu School, but last November also made proposals for establishing schools that could accommodate migrant children, providing the Provincial Education Office with a fund of two million yuan to set up a special programme for the compulsory schooling of these children and forcing the municipal bodies in charge of finance and education to create public schools to receive migrants ${ }^{64}$. The municipality of Chengdu seems somewhat more hesitant and divided. For one thing, it has obtained permission from the Sichuan People's Congress for exemption from the provincial reform of the hukou, enabling migrants having a fixed income and housing to become urban citizens ${ }^{65}$. Secondly, control of migrants there is less strict than in the major cities of the east ${ }^{66}$ and the mayor has given his symbolic support to the director of Yangfan who had come to seek his help by stating that Chengdu had to create its own model for finding a place in school for migrant children $\left({ }^{67}\right)$, while the Education Office has given its support to Bashu. However, the municipal government has still not published any legislation concerning the schools for migrant children, which leaves a doubt hanging over its position, between support and repression, something that the government of Chenghua district is complaining about, asking it to strengthen its means of eradicating these schools ${ }^{68}$. Finally, the governments of the administrative villages and districts remain, essentially for economic reasons, refractory to the lifting of barriers that are standing in the way of equal rights for migrants and urban residents alike. While the latter may retain their full powers as far as the authorisation of schools goes, their power of repression is limited by national legislation, the position of the Provincial Congress and the ambivalence of the municipal government which refuses to align itself to their position, yet without granting the funds needed to resolve these contradictions. The question now is to know if the policy of developing the west will result in a demographic rebalance between rural residents and those in the city so that, in the fashion of Xiamen, the municipality of Chengdu can combine its interests with those of the immigrant workers.

China has been undertaking economic reforms for nearly a quarter-century now, but during this time it has not questioned a system of residency that has on the contrary been reinforced by the policies of decentralisation, thereby counteracting the apparently universal import of legislation in the area of education. In a general way, people who come-directly or through family ties-from the countryside remain second-class citizens. The mediocrity of the education system in rural areas and the hurdles placed in the way of the schooling of children in urban areas are depriving them of equal opportunities with urban residents. In town, the practice of the authorities remains largely discriminatory and the label "migrant" persists as a stigma 
with a very good chance of being passed on to future generations. The Chinese state continues to put up obstacles to the recognition of schools for migrants. Yet, at the same time, it has been able to guarantee the existence of a private educational sector for city residents, which reveals a lot about the contradictions and failures of the system. Until now, the government has had individuals bear the brunt of the cost of the disparity between economic reforms and political reforms, but over the past year or so there have been signs of a new awareness within the ruling elite. The cost paid by individuals ends up being borne by the country as a whole, and the Party risks being its first debtor. The developing consciousness of the attendant risks thus lets one hope that special attention will be given to the right to an education for all, which is the pillar of the regime's intangible principles of social stability and economic development.

\section{NOTES}

1.Eric Florence, "Les migrations en Chine et leurs implications sur le plan urbain" ["Migrations in China and their Urban Implications"], Hommes et migrations, No. 1220, July-August 1999, p. 117.

2. "Hope for Children of the Floating Population to Attend School", translation from China Education Daily, June $7^{\text {th }} 1996$.

3.Shutting Out the Poorest: Discrimination Against the Most Disadvantaged Migrant Children In City Schools, Report, May 2002, available at the website: www.hrichina.org.

4.Survey conducted in January 2003 in co-operation with the company Nanguang zhifang for the Programme of Support for Migrant Workers in Chengdu under the direction of the Federation of Women of Sichuan Province and the Sichuan Academy of Social Science in co-operation with UNESCO.

5.According to official figures, that are in fact known, in order to present the education situation in the countryside in a favourable light, the relation between rural and urban zones concerning state expenditure in the field of education would be of the order of 1:1.66 for primary schools and 1:1.67 for junior secondary; Human Rights in China, Institutionalized Exclusion: The Tenuous Legal Status of Internal Migrants in China's Major Cities, Report, November 2002, p. 15, available at the website: www.hrichina.org. 6.These are institutionalised and generalised nationally by the Regulations concerning the Registering of Households in the People's Republic of China, voted by the Permanent Committee of the National People's Congress, January $9^{\text {th }} 1958$.

7.Guarantee of a job for life with the accompanying perks of a flat and the provision of food and basic consumer items.

8.Guojia zhuxi ling 38 hao, Zhonghua renmin gongheguo yiwu jiaoyufa (Decree No. 38 of the President of the PRC, ratified by the NPA on July 1st 1986); all the bills that we cite may be consulted in Chinese at the website for official legal information: www.law.com.cn. 9.Quanguo renda, Zhonghua renmin gongheguo jiaoyufa.

10.Guojia jiaowei, gonganbu, Liudong ertong shaonian jiuxue zanxing banfa. They had been preceded in 1996 by the Trial Measures for the Education in Cities and Townships of the 
Children and Adolescents of the Migrant Community, published by the State Commission for Education, which designated a few pilot sites in some of the major cities where these measures were to be "trialed". The 1998 Measures have been extended to the whole of the country.

11."Dagongzhe zinü, yao jin xuexiao you duo nan" (How difficult it is to gain admission to a school for the children of migrants), Sichuan ribao (Sichuan Daily), September 11th 2002; Human Rights in China, Shutting Out the Poorest..., op. cit., p. 12.

12. "Yiwu jiaoyu xuexiao shoufei guanli zanxing banfa" (Temporary Measures Concerning the Management and Raising of Compulsory Fees by Schools).

13.Sichuan ribao, September 11th 2002.

14.Interview with parents, January 22nd 2003.

15.Jasper Becker, "Forget About Hotels and Roads, Spend the Money on Children's Education, Say Deputies", South China Morning Post, March 15th 1999.

16.HRIC, Institutionalized Exclusion, op. cit., p. 21.

17.Guowuyuan jiufengban, Jiaoyubu guanyu jin yi bu zuohao zhili jiaoyu luan shoufei gongzuo de yijian, (Proposal of the Bureau for the Correction of the Style of Work of the State Council and the Ministry of Education on how to settle the question of the arbitrary levying of school fees), published on June $12^{\text {th }} 2001$.

18. Chengdu wanbao (Chengdu Evening Post), February $17^{\text {th }} 2003$ and March $25^{\text {th }} 2003$.

19. Chengdu wanbao, April 10th and 16th 2003.

20.Interviews with parents of students at the school, Bashu, Chengdu, January $22^{\text {nd }}$ 2003.

21.According to the figures of the municipal government of Peking, the city's public schools had a surplus of 300 places, HRIC, Shutting Out..., op. cit., p. 4.

22.Interviews with parents of children at Bashu School, January $22^{\text {nd }} 2003$.

23.Idem.

24.Interview with Li Shumei, founder of Xingzhi School, in Han Jialing, "Beijingshi liudong ertong yiwu jiaoyu zhuangkuang diaocha baogao" (Research report on the situation of migrant children of compulsory school age in the municipality of Peking), Qingnian yanjiu, No. 8, 2001, p. 74. See also Astrid Fossier, Les enfants issus des populations flottantes, quelle scolarisation?, [What schooling for children from a floating population?], Masters thesis in Chinese, University of, Paris 7, September 2002.

25.Han Jialing, op. cit., p. 75.

26.HRIC, Institutionalized Exclusion, op. cit., pp. 29-32 and Han Jialing, op. cit., pp. 76-77.

27.Guo Fugeng and Gao Yu, "The Difficulty Migrant Children Have in Enrolling in School Cannot Be Ignored”, translation from Guangming Daily, March $25^{\text {th }} 1997$.

28.Han Jialing, op. cit., p. 72.

29.Idem, p. 77.

30.Liu Wei, "Liudong renkou zinü dao nar qu dushu ?" (Where can children from a floating population go to study?], Zhongguo jiayu bao (China Education News), May $24^{\text {th }}$ 1998.

31.Guowuyuan, Shehui liliang banxue tiaoli.

32.Quanguo renmin daibiao dahui changwu weiyuanhui, Zhonghua renmin gongheguo minban jiaoyu cujinfa.

33.These surveys, from which the following information is derived, were carried out between January and April 2003.

34.Sichuan sheng minban jiaoyu jigou fenlei shezhi biaozhun. 
35.Shehui liliang banxue (youeryuan) banshi chengxu, published, as far as Wuhou district is concerned, on March $26^{\text {th }} 2002$.

36.State Council Regulations for the Establishment of Schools by the Social Forces (arts. 45 and 46), Sichuan Province Regulations for the Establishment of Schools by the Social Forces (art. 39), Temporary Measures for the Schooling of Children and Adolescents of the Migrant Population (arts. 4 and 9 ).

37.This is the case for example of Yangfan, but also of Caiyi and Zhengxing Schools, which are both located in Jingniu district.

38. Complaint made to the top officials of Bashu School. As an example of this, the document quotes some passages from the article: "[...] in the middle of one of the classrooms, a wooden pole on the ceiling supports a swinging beam on the point of collapse, and all the walls have cracks in them"; "Xiao Hongtao, the school's principal, is possessed by a frantic desire to get rich, [...] all the teachers at the school are either close or distant relatives, none of whom have any accreditation".

39.The Regulations for the Establishment of Schools by the Social Forces of the State Council and Sichuan Province, as well as the 1995 Law on Education in the PRC, stipulate that any non-government educational institution has a public service mission to fulfil and must consequently demonstrate that it has clearly non-lucrative objectives.

40.Interview with Gan Bingxiang, co-founder with his wife of Bashu School and close associate of the founder of Kaiming School, February $22^{\text {nd }} 2003$.

41.Jinbei School which has 210 students and Yuran School which has 120.

42.Regulations of the State Council for the Establishment of Schools by the Social Forces (art. 39), Regulations of Sichuan Province for the Establishment of Schools by the Social Forces (art. 32).

43.Idem art. 47 and art. 40.

44.Zui jinji de huyu, zui qianglie de yaoqiu (A most urgent call, a most insistent request). 45.Chengdu shi Wuhou qu renmin fayuan gonggao (Declaration by the Wuhou District People's Tribunal), December 17th 2002.

46.Chengdu shi fangwu anquan jianding bangongshi wenjian (Document from the Department for evaluating the security of buildings in the municipality of Chengdu), December 24th 2002.

47.1998 Measures.

48.Several articles devoted to this school appeared in the local press, for example: "Nongmingong zidi xuexiao zhuang zheng le" (A school for the children of migrants has just got a licence), Chengdu shangbao (Chengdu's newspaper for trade and commerce), July 2nd 2002 and "Shen chu guan'ai de shou" (Holding out a kind hand), Chengdu wanbao, January 3rd 2003. The television broadcast Xianchang (In situ), sponsored by China Telecom, also had a report on it.

49. This group of volunteers, formed in 1997, which brings together about 4,000 students from the University of Sichuan, mostly members of the Communist Youth League, is involved in pedagogical and social work aimed at several groups (young criminals, elderly people, children of poor rural farm workers, etc.) in exchange for which the students get "bonuses" that will enable them to obtain help from the Party and society in case of need; interviews with members of this group, late January 2003. 50. “Youths Criticise Migrant's Treatment", South China Morning Post, March $5^{\text {th }} 2003$. 51.This practice developed in China in the 1980 s to enable organisations, that had been formed independently, to acquire a legal status. In particular this was the case for editorial committees that registered with official publishing houses and thus came 
under the responsibility of their Party committee while still functioning, in practice, in a relatively autonomous manner. See Jean-Philippe Béja, “ Regards sur les 'salons' chinois " [A look at Chinese 'salons'], Revue française de sciences politiques, February 1992; Chen Yan, L'Eveil de la Chine, [China's Awakening] L'Aube, collection Essai, 2002, pp. 88-89 ; and Chen Fong-Chin and Jin Guantao, From Youthful Manuscripts to River Elegy, Hong Kong, The Chinese University Press, 1997.

52.Guanyu jiejue wo qu liudong renkou zinü ruxue ji xiangguan wenti de qingkuang baogao (Report on the schooling of children from the migrant population and other related issues in our district).

53.Idem.

54.HRIC, Shooting out ..., op. cit., p. 17 ; Han Jialing, op. cit., pp. 75-76.

55.Researcher in the Institute of Sociology at the Chinese Academy of Social Sciences, op. cit.

56.These reports, for internal use, are not often released, but one can read snippets about them in the press; see, for example, "Concerns About the Education of Second Generation Migrants", translation from China Youth News, October 11th 2001, "China Makes Schooling for Migrant Children Easier”, China People Daily, October 7th 2002, "Mingong zinü ruxue tixian shehui gongzhen" (The schooling of migrant children is the embodiment of social equity), Nanfang Zhoumo (The Weekend of the South), April 10th 2003. See also Zhao Shukai, Conflict and Government Change About Management of the Floating Population, published at www.wiapp.org and Cui Chuanyi, "Pochu dui nongmingong jiuxue qishi" (Eliminating educational discrimination against migrant children), Jingji cankaobao (Economic review), April $18^{\text {th }} 2002$.

57.He Nanying, "The Phenomenon of 'Little Urban Illiterates' Makes People Worry", translation from China Women's News, December $20^{\text {th }} 1996$.

58.Nanfang Zhoumo, April $10^{\text {th }} 2003$.

59.Guowuyuan guanyu jichu jiaoyu gaige yu fazhan de jueding.

60.Guowuyuan bangongtong tongzhi, Zuohao nongmin jingcheng wugong jiuye guanli he fuwu gongzuo, January $16^{\text {th }} 2003$.

61.HRIC, Shutting out..., op. cit., pp. 4 and 12.

62.Chengdu wanbao (Chengdu Evening News), March $16^{\text {th }} 2003$.

63.Nanfang zhoumo, April $10^{\text {th }} 2003$.

64.Sichuan ribao (Sichuan daily), November 29th 2003 and Tianfu zaobao (Tianfu Morning Paper), December $9^{\text {th }} 2002$.

65.Idem.

66.The results of our study confirm the analysis presented by Anita Chan in "'A Race to the Bottom': Globalisation and China's labour standards", China Perspectives, No. 46, March-April 2003, pp. 41-49.

67.Interview with Zhou Yong'an, January $19^{\text {th }} 2003$.

68.See note No. 52 . 